\title{
Climate-Smart Agriculture in Cascade Minor Irrigation System: Status, Scope and Challenges in Sri Lanka: A Case from Puttlam District
}

Sri Lanka Journal of Social Sciences and Humanities Volume 1 Issue 2, August 2021: 109-122 ISSN: $2773692 X$ (Online), 27736911 (Print) Copyright: (C) 2021 The Author(s)

Published by Faculty of Social Sciences and Languages, Sabaragamuwa University of Sri Lanka Website: https://www.sab.ac.lk/sljssh DOI: http://doi.org/10.4038/sljssh.v1i2.43

\author{
Sakalasooriya, N.P. ${ }^{1, *}$ \\ ${ }^{1}$ Department of Geography, University of Kelaniya, Kelaniya, 11600, Sri Lanka.
}

Received: 24 February, 2021, Revised: 01 April, 2021, Accepted: 09 May, 2021.

How to Cite this Article: Sakalasooriya, N.P. (2021). Climate-smart agriculture in cascade minor irrigation system: Status, scope and challenges in Sri Lanka: A case from Puttlam District. Sri Lanka Journal of Social Sciences and Humanities, 1(2), 109-122.

\begin{abstract}
This paper discloses the status, scope, and challenges in familiarizing the climate-smart agricultural (CSA) practices to the cascades or terraced tank clusters in the Puttalam district in the Dry Zone (DZ) of Sri Lanka. As a tropical country, Sri Lanka faces many challenges reducing the gap of trade balance in the economy. Reducing food imports can be considered as one of the solutions. Consequently, Sri Lanka is paying high attention to introduce the CSA practices for the DZ while identifying the most productive interventions. Karuwalagaswewa DSD of Puttalam district is one of the driest DSDs in the DZ of Sri Lanka and it has been recognized as a hotspot area to improve the agricultural livelihoods of the farming community residing in the highly vulnerable areas of the DZ. The secondary data of the study have been abstracted from the district and DSD level reports while selected PRA tools, FGDs, participatory map, seasonal calendar, Metrix rankings, and survey methods have been applied for collecting the primary data from Neliwewa, Ihala Ralapanawa, and Rambawewa Terraced Tanks Clusters in the DSD. The study discloses that current agricultural practices of Puttalam district are mostly traditional and there is a high probability to introduce the CSA practices. The major challenge of introducing the modern CSA is intragenerational and intergenerational attitudinal conflict and lack of scientific understandings of modern technologies in CSA. A systematic participatory approach is essential to sustain the CSA practices.
\end{abstract}

Keywords: Cascades, Climate change, Climate Smart Agriculture, Dry Zone

\section{INTRODUCTION}

This article investigates the status, scope, and challenges for promoting climate-smart agriculture (CSA) in Sri Lanka with special reference to Karuwalgaswewa Divisional Secretariat Division (DSD) in the Puttlam District. The article is based on the PRA and survey results which have been collected from the 03 cascades of Karuwalagaswewa DSD. The first part of the article focuses on the water supply to the crop cultivation while the agricultural production and related situations are discussed in the middle part and finally discloses the marketing and value chains of the agricultural production in the Puttlam district.

\section{LITERATURE REVIEW}

Sri Lanka being an Upper Middle-income country with a population of 21.67 million (DCS, 2018), $82 \%$ of them are in rural areas. The GDP growth rate of Sri Lanka is $3.2 \%$ and the contribution of the agriculture sector to the GDP is $7.0 \%$ (DCS, 2018). However, it should be noted that the agriculture sector generates $25.5 \%$ of employment on the island according to the Department of Census and Statistics (2018). Conversely, Sri Lanka has been identified as the second most vulnerable country to climate change according to the Global Climate Vulnerability Index in 2018. Thus, the impact of climate change on the agriculture sector and its employment is a grave concern in the context of food security despite the lower sector contribution to the economy.
The dry zone of Sri Lanka, being the most agriculturally productive region of the country often affects by the water shortage and has a long history of irrigation-based water management for agricultural production. The expansion of crop cultivation into the north, east, and southeast dry zones of the country was enabled through the construction of elaborate water management systems, dating back to the period between $500 \mathrm{BC}$ and $300 \mathrm{AD}$. The systems are based on water capture in small reservoirs commonly known as 'tanks' connected through canals forming cascades. However, with the expansion of large-scale water storage and irrigation infrastructure, these small tanks system in the dry zone of Sri Lanka was paid low attention. Nevertheless, with the emergence of water resource management at the forefront of the development agenda, the importance of small tank system management was highlighted. Recently, water scarcity has often been observed in the region as a result of inter-annual and inter-seasonal variability in rainfall, variations in the catchment area, and associated land-use changes while reducing the proportion of rainfall available for capturing in downstream tanks despite the growing demand for water to meet the needs of the growing population.

Extreme weather events are becoming increasingly common in Sri Lanka and dry zone areas of the country have been af-

\footnotetext{
* Corresponding author: Tel.: +94 (71) 802 6162; Email: nishan@kln.ac.lk, sakalasooriyanp@yahoo.com (iD) https://orcid.org/0000-0001-8400-9747
} 
fected by cycles of floods and droughts, imposing considerable costs for relief and rehabilitation according to the Ministry of Disaster Management. In the dry zone, the negligence of the system of cascading tanks has meant a lack of adequate storage facilities which in turn, has resulted in high runoff owing to extreme rainfall events - which dump large amounts of rainfall during a relatively shorter period - causing serious crop damage and floods. Significant changes of monsoons with high-intensity rains, and a very short rainy season with long dry spell experienced in the area. Also meant droughts and drinking water shortages within 3 or 4 months after floods, requiring the sourcing and provision of drinking water from tanks at distant (and more expensive) locations. Outside extreme events, increased variability has been observed in monsoon behavior, onset time, duration, nature of rainfall, and seasonal rainfall, although total annual rainfall has remained virtually steady. Both daytime maximum and night-time minimum air temperatures show increasing trends at most meteorological stations in the country. Farmers and agricultural workers bear the worst impacts of the increased frequency of floods, droughts, and heat stress resulting due to climate change.

Given the centrality of tanks in the agrarian livelihoods in the dry zone of Sri Lanka, their current levels of negligence and the increasing vulnerability of these areas to both droughts and floods in quick succession due to the climate change scenario is a major concern of the policymakers. Consequent impacts on agricultural production and incomes in these areas are the driving force for the rehabilitation of tank-based irrigated agricultural systems in improving the resilience of these areas and the agrarian communities that depend on them.

The Physical Setting of the Hotspot Area: Karuwalagaswewa is one of the significant DSDs among the 16 DSDs of the Puttalam District which is located near the Western coast of the Northwestern Province in the Dry Climatic Zone (DCZ) of Sri Lanka. Kala Oya and Modaragam Aru rivers demarcate the northern boundary of the Puttalam District and Ma Oya from the South. The Western part of Anuradhapura and Kurunegala District is the eastern limits of the district which has an area of $3,072 \mathrm{~km}^{2}$. The Indian Ocean is the western boundary of the district (See Fig. 01). The total land area of the district is about $2,882 \mathrm{~km}^{2}$ and the $190 \mathrm{~km}^{2}$ area is covered by lagoons and internal water bodies. The population of the district is 7.6 million (2019) and population density is 250 per km² (Department of Census and Statistics, 2019).

Figure 01: Geographical location of the Karuwalagaswewa Hotspot Area in Puttalam District

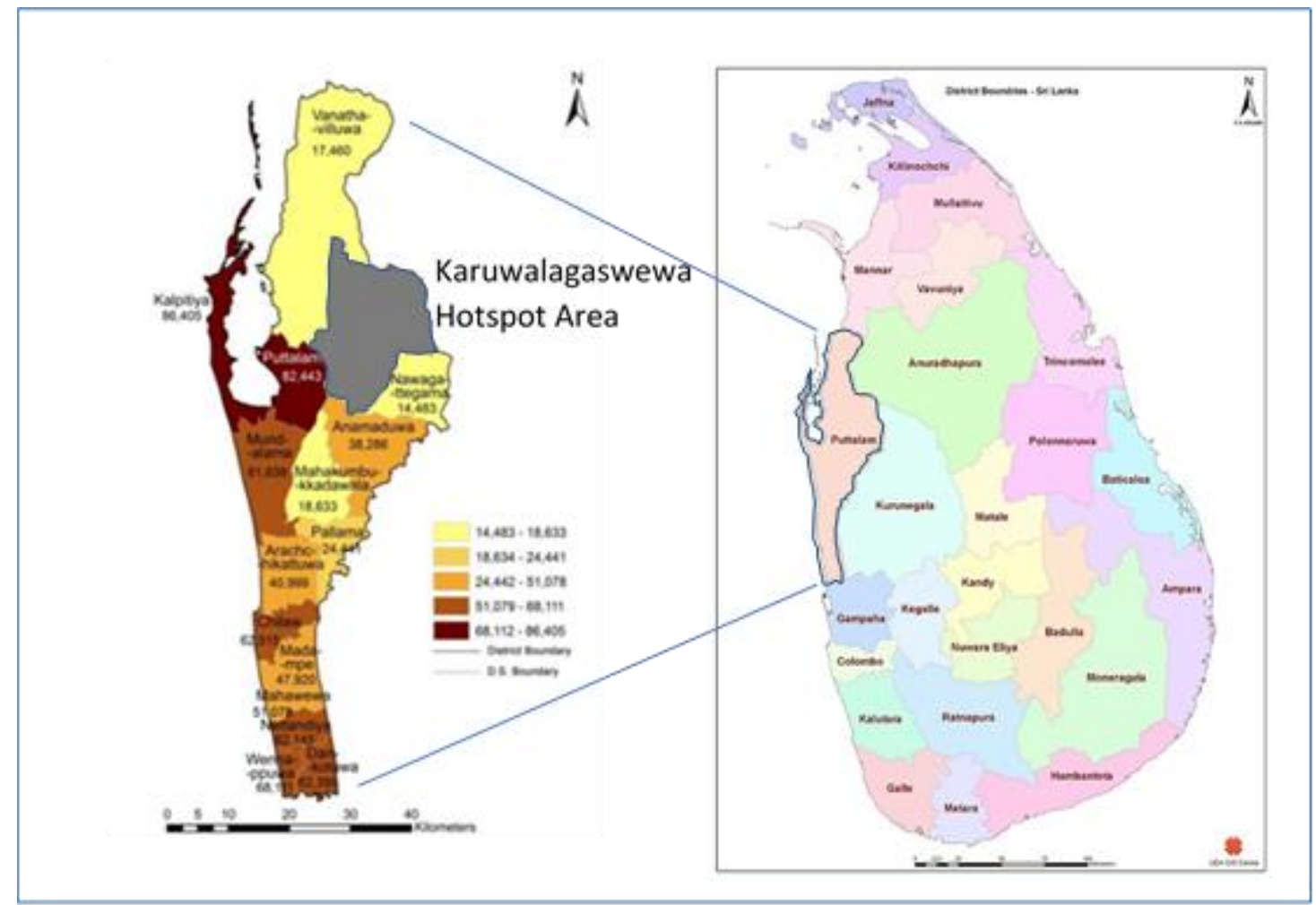

Source: Compiled by the author

The average elevation of the Karuwalagaswewa DSD is about 85-200 meters above the mean sea level. Karuwalagaswewa DSD is surrounded from North by Kala Oya and Vanathavilluwa DSD, East by Giribawa DSD of Kurunegala District, South by Anamaduwa and Navagaththegama DSDs, and West by Puttalama DSD as the boundaries. Karuwalagaswewa Divisional Secretariat Division is one of the largest
DSDs with a land area of $490 \mathrm{~km}^{2}$. Though some of the err sources have pointed out that the Karuwalagaswewa DSD is located in the semi-arid climatic zone, it belongs to the Dry Climatic Zone of Sri Lanka because of the mean annual rainfall of the DSD varies from $760 \mathrm{~mm}$ to $1,600 \mathrm{~mm}$. On the other hand, there is no semi-arid climate in Sri Lanka. 
Figure 02: Annual Rainfall variation of The Karuwalagaswewa hotspot area

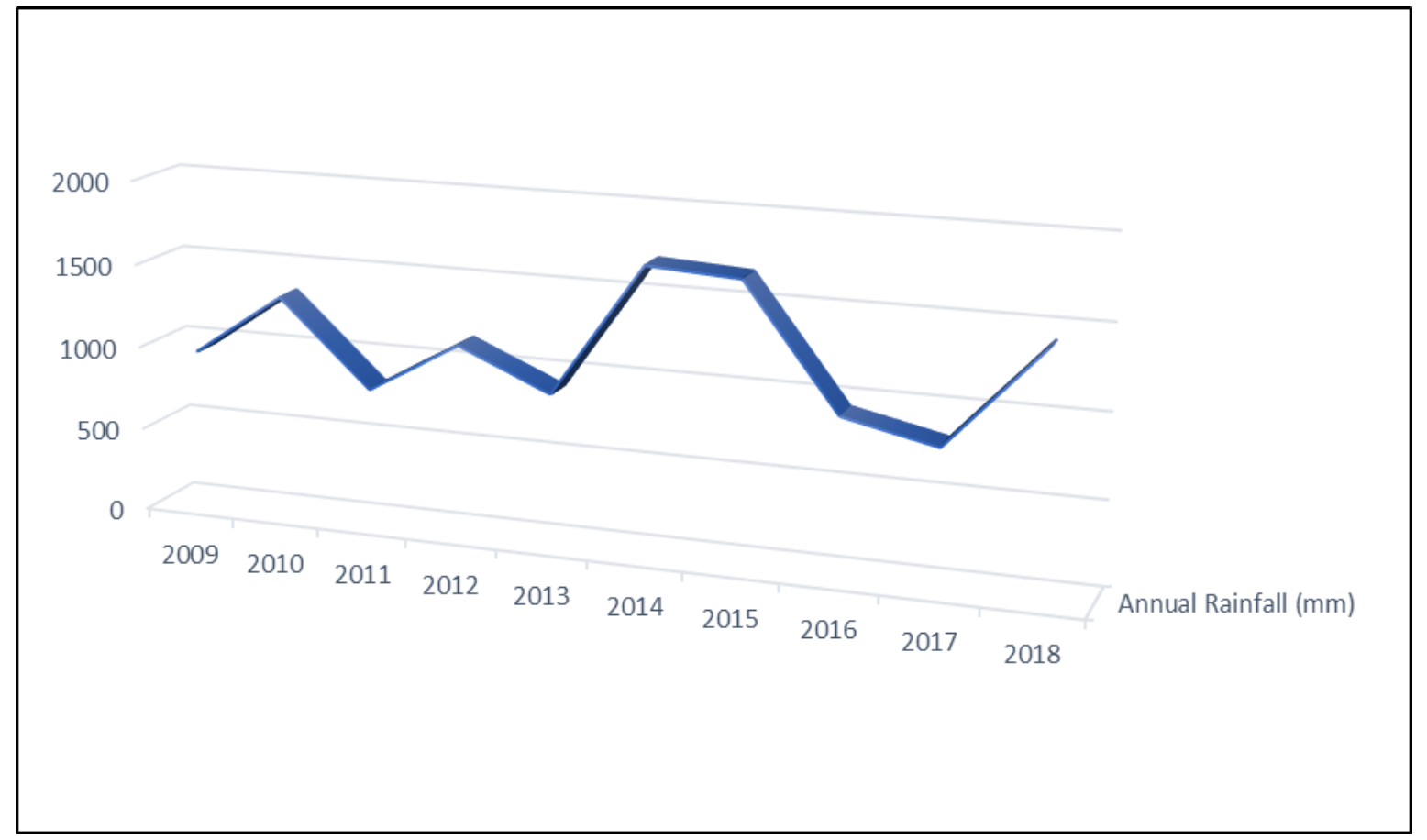

Source: Resource Profile of Karuwalagaswewa, 2018

Due to the relative and absolute location of the DSD, it faces four climatic periods during a year. It has a 04-month rainy season from November to February and $2 / 3$ of the total rainfall is received from Northeastern Monsoon during this season. In the months of March and April, a very low amount of rainfall is received from convectional currents as it is the inter-monsoonal period. Throughout the period from May to August a small amount of rainfall with heavy thunderbolts is received from conventional currents due to the activation of the Southwestern Monsoon.

The effective evaporation is higher than the rainfall during this period and this cascade consequently faces the seasonal

Table 01: Drainage system of the Karuwalagaswewa DSD area

Name of the natural tributaries and manmade canals.

Pathane Ela*

Rajangane Ela*

Neela Bamma Yodha Ela*

Radavi Bandi Ela*

Mi Oya

Kumbukkalla Oya

Karamba Oya

* Man-made canals and annual droughts. Due to very specific weather conditions, a high amount of rainfall exceeding $200 \mathrm{~mm}$ is received in May causing flash floods in the DSD (Department of Meteorology, 2020). The highest amount of rainfall is received during November and December due to the Northeastern Monsoon. Consequently, the annual seasonal flood is common in the area as the landscape is low gradient undulating flat and most probably faces cyclones with the heavy rains. Adapting to the climate and physical settings of the DSD, 71 villages have been divided among $26 \mathrm{Grama} \mathrm{Ni-}$ ladari Divisions (GND). The total population is 30,441 in 9,664 families (2018); with 9,012 males and 9,284 females (Department of Census and Statistics 2012; Puttalam District Statistical Handbook, 2019).

Sources: Resource Profile 2019 and the PRA Results, 2019/2020 collected by the author

The drainage is very weak because of the low gradient landscape. The Kala Oya and the Mi Oya flow through the DSD. The runoff water of the 03 cascades, Neliwewa, Ihala Ralapanawa, and Rambawewa runs through the tributaries of these two major rivers to the Indian Ocean. The water volume of all these natural waterways significantly reduces in the dry period or Yala Season of the year. According to the data, the Karuwalagaswewa hotspot area is located in the Dry Climatic Zone of Sri Lanka which is on an undulating peneplain. The 03 cascades have to be developed under the project in the Karuwalagaswewa DSD. The cascades of Neliwewa, Ihala Ralapanawa, and Rambawewa are in the Karuwalagaswewa DSD (See Fig. 03). The Neliwewa cascade is located on the southern tip of the hotspot area and the other 
02 cascades lie on the northeastern boundary of the hotspot area.

\section{Approach and Methodology}

The mixed method under the inductive approach has been applied for primary data collection and both qualitative and quantitative data and information have been collected. Depending on the schedule, some of the RRA methods, FGDs, participatory map, seasonal calendar, Metrix rankings, and survey methods have been applied. The data from DSD offices, resource profiles, data from ASCs, district and statistical handbooks, relevant websites, and field notes of the field officers in the region were the main secondary data sources. Satellite images, Google Earth Maps, and images, 1: 50,000 and One-Inch maps have been used to interpret the spatial data of the regions.

The PRA assessments have conducted using the carefully selected tools of PRA. The two types of methods have been utilized for the participatory assessment. The smaller groupbased assessments have been conducted on an individual tank basis with a few well-informed farmers, leaders, and of- ficials of the local farmer organizations and captured the status, challenges, opportunities, and interventions for coalitions. A larger group-based assessment was conducted with at least $50 \%$ of farmers including women, to adjust, order, and prioritize the list of interventions, as well as the details such as location, interesting set of participants' beneficiaries, were obtained. Then, likely costs, benefits, and risks or special requirements have been identified. The social resource and hazard mapping have been conducted at the cascade level of the well-experienced and knowledgeable 05 to 07 farmers and both the women and men attended the discussion from each tank. The tool of the seasonal calendar was also practiced on a cascade basis. Two members including one expert and an assistant facilitated the discussion to identify the seasonal crop pattern, the cultivation practices, and the other seasonal practices in the cascade. The transact walks were done in each tank to establish a rapport with the local farmer communities and obtained preliminary information and understood the geographical setting as well as the socio-demographic features on an individual tank specific and cascade basis.

Figure 03: Location and Land use of the Cascades in the Karuwalagaswewa hotspot area

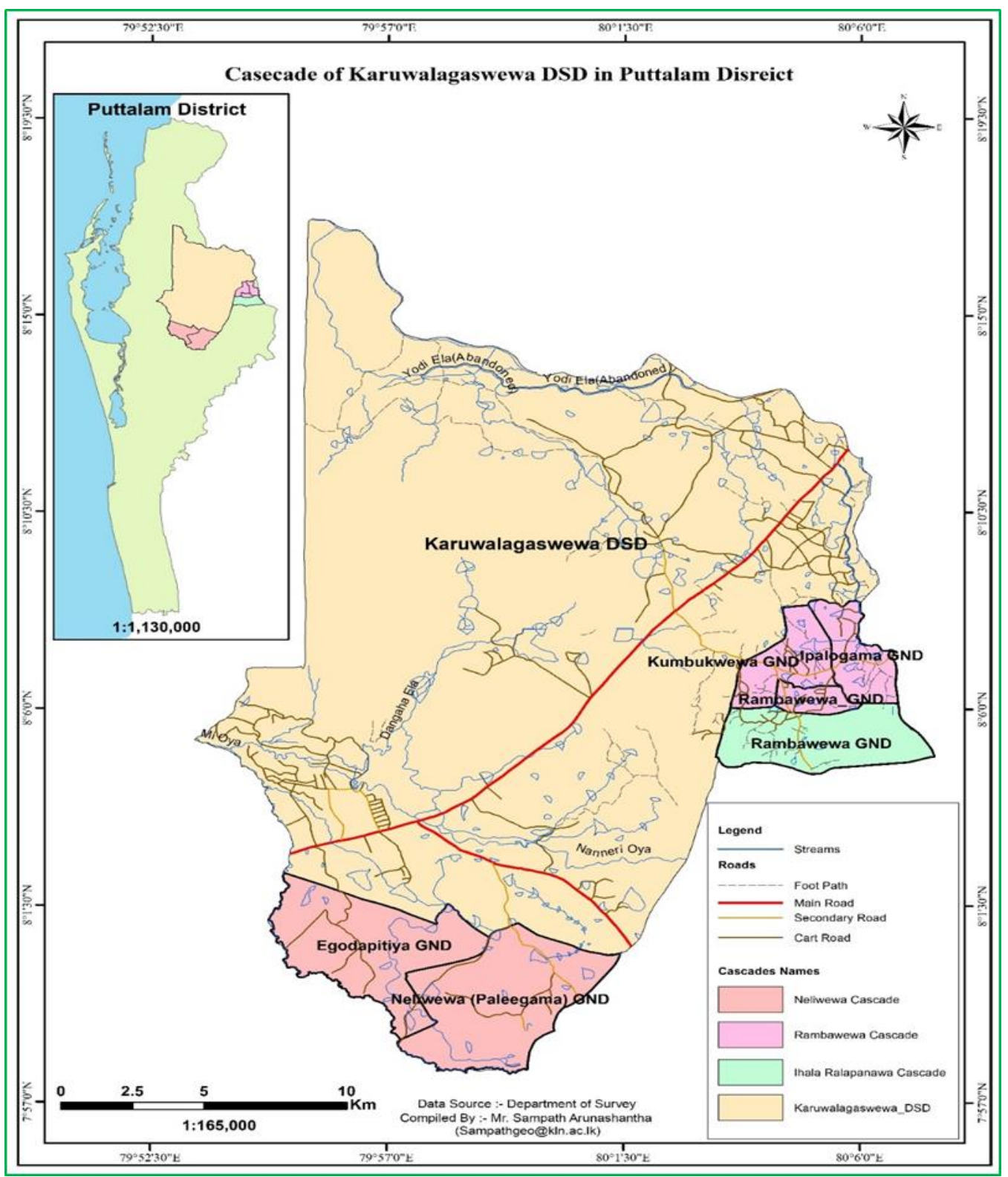

Source: Compiled by Arunashantha, S. 2021 


\section{RESULTS OF THE STUDY}

Cultivation in the tank command areas: Three crop cultivation areas of the cascades can be identified as command areas, highlands, and home gardens in the cascades of the district. The crops and the cultivation areas are varied among the cascades. The data proves that paddy cultivation is the major crop in the command areas in the Maha season while maize, groundnuts, cowpea, watermelon, long bean, chili, and black gram are cultivated in the Yala season. The normal crops of the highlands and home gardens are highly diversified by the temporal pattern of the climate, physical conditions of the soil, attitudes of the farmers, market prices, water sources, wild animal threats, pest attacks, storage facilities, government policies, and technological advancements.

Paddy, groundnuts, maize, cowpea, chili, and watermelon are the major crops cultivated in the command areas of the Rambawewa cascade. Paddy is the major crop cultivated in both seasons. During the rainy seasons, the farmers cultivate on the highlands and in home gardens. The agriculture in highlands and home gardens depends on the rainfall and some of the farmers have agro wells and tube wells. Coconut, maize, groundnut, sesame, millet, cowpea, green gram, black gram, cashew, mango, orange, lemon, banana, watermelon, long bean, and chili are the common crops grown in the highlands.

Coconut, banana, mango, and lemon are the most common perennial crops in the home gardens while watermelon, eggplant, long bean, chili, and tomato are the popular crops grown in the homesteads in the Rambawewa cascade. The study shows that there are 09 major crops including paddy, maize, groundnut, sesame, millet, cowpea, green gram, chili, brinjal, black gram, and watermelon in the command areas of the tanks in Ihala Ralapanawa cascade of the Karuwalagaswewa hotspot area. Coconut, maize, groundnut, sesame, millet, cowpea, green gram, and cashew are cultivated in the highlands while coconut, groundnut, cowpea, green bean, eggplant, and watermelon are the popular crops in the home gardens.

Cropping Pattern of tank command areas: Paddy is the major crop cultivated in all the command areas of the tanks of the cascades in the Karuwalagaswewa hotspot area in normal rainfall years. The tank command areas are varied depending on the water storage capacities of the tanks in the cascade. However, paddy cultivation is carried out in both seasons as the major type of cultivation. Many of the tanks possess an adequate amount of water for the Yala season as the farmers carry out limited paddy cultivation in the command areas during the Maha season. Some of the tanks of the cascades, "Kulu wew", "Kayan wew ", Nana wew ", and "Pin Wewa" do not have command areas (Mendis, 2002; Thennakoon, A.M.U. 2012; Maddumabandara, C.M. 1985; Panabokke, C.R. 1999, 2002, 2009; Dharmasena, P.B. 2015, Sakalasooriya, N, 2019;2020, 2021).

Paddy is the most common crop cultivated in both seasons in the Rambawewa cascade. According to the data, there is a huge difference in the cultivated land area between the Yala and Maha seasons. A land area of 444.5 acres has been cultivated in Maha season while only 69 acres have been cultivated in the Yala season in the same rainfall year. The cropping pattern of the tank command areas is varied in normal rainfall years, drought years, and the seasons of the Ihala Ralapanawa cascade. However, Maha is the main crop season of the DZ. Though 276.5 acres have been cultivated in the normal rainfall year, only 89 acres have been cultivated in the same year in the Yala season. Though paddy is cultivated in 550 acres in Maha season in normal years, only 446 acres have been cultivated in the same year due to the malfunctioning of the minor irrigation of the cascade system of the Neliwewa cascade. Other seasonal crops are cultivated in the command areas during the Maha season under the rainfed water and minor irrigations like small tanks in cascades. Thus, all the cascades of the hotspot area should be developed to enhance water availability and to reduce the drought years.

Cropping Pattern of highlands and homesteads: The seasonal crops are cultivated in a land area of 36.8 acres and 15.8 acres in the highlands during the Yala and Maha seasons respectively. The homestead cultivation has been carried out in a land area of 337.45 acres and 37.45 acres in the Yala and Maha seasons. Coconut and banana are the dominant perennial crops of the cascade which are grown in the highlands and homesteads. Vegetables, groundnuts, and chili are the most drought-resistant seasonal crops grown during the Yala season.

There is a total land area of 495 acres and 31.5 acres in highlands and homesteads respectively. Similar to the Neliwewa cascade, in the Rambawa cascade also the crops like coconut, banana, and cashew are meant to be common in the highlands while black gram, maize, groundnut, chili, and millet are the dominant crops that are cultivated during the Yala season. The farmers cultivate some of the seasonal vegetables in the homesteads in both the seasons because of having adequate highlands to cultivate and the unpredictable rainfall patterns in the Maha season. There is a large difference between the grown acres between the seasons during the last 05 years due to lack of rainfall. The significant observation is that all these cultivations are very limited to a small land area compared to the total extents of the cascades. Water scarcity, drought, and floods are the major problems faced by the farmers who engage in cultivations in the highlands and homesteads.

Current water sources of the DSD

There are 62 tanks and diversions (anicuts or Amuna) in the 03 cascades with 1,740 direct beneficiaries of the Karuwalagaswewa hotspot area in the Puttalam District. The cascades are located in 02 ASC areas, Thabbowa and Ihala Puliyankulama. The Neliwewa Cascade is in the Thabbowa Agrarian Service Center (ASC). Rambawewa and Ihala Ralapanawa cascades are collected data in the Ihala Puliyankulama ASC. The details of the number of direct beneficiaries by cascades have been mentioned in Table 02. Although the Rambawewa cascade is the largest in terms of the number of tanks, Neliwewa has the highest number of direct beneficiaries. According to the data, 13 tanks of the Rambawewa cascade, 8 tanks of the Ralapanawa cascade, and 04 tanks of the Neliwewa cascade have not been registered yet. Consequently, these tanks and their command areas also have not been renovated for decades. This is also one of the major factors for limiting the irrigation water for agriculture (See Table 02). 
Table 02: Tanks and anicuts system of the Cascade and their beneficiaries

\begin{tabular}{|c|c|c|c|c|}
\hline 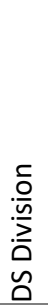 & y̌ & 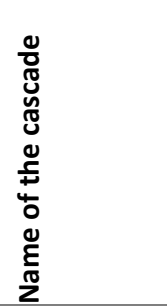 & 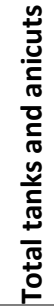 & 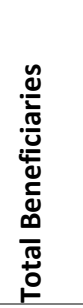 \\
\hline \multirow{4}{*}{ 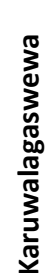 } & Thabbowa & Neliwewa & 15 & 831 \\
\hline & $\begin{array}{l}\text { Ihala Puliyanku- } \\
\text { lama }\end{array}$ & Ralapanawa & 19 & 368 \\
\hline & $\begin{array}{l}\text { Ihala Puliyanku- } \\
\text { lama }\end{array}$ & Rambewa & 28 & 541 \\
\hline & Total & & 62 & 1740 \\
\hline
\end{tabular}

Source: PRA results in 2019/2020 collected by the author

Command Areas to be irrigated: After renovating the tank system of the Neliwewa cascade, the farmers would be able to cultivate a total land area of 576 acres and 404 acres respectively in the Maha and Yala seasons. The current extent of land allocated for maize will also be extended by 80 acres in Yala and 05 acres in Maha. After renovating the tank system successfully, 55 acres of chili and 20 acres of onion will be able to cultivate in the Yala season. If these changes take place after the renovations, they would be really helpful to reduce the underemployment, unemployment of the youths, and to increase the income of farmers. After rehabilitating the Rambawewa cascade, farmers will be able to cultivate a total land area of 416 and 290 in the Maha and Yala seasons respectively. Farmers hope to cultivate watermelon in the command areas in both seasons after the rehabilitation of the cascade. After the renovation of the Ihala Ralapanawa Cascade, farmers will be able to cultivate a total land area of 310 and 300 acres in Yala and Maha seasons respectively.

According to the field experience, some areas of the tank and tank ecosystems have been encroached by the settlers and some of the areas have been demarcated as forest reservations by the Forest Department. Consequently, some legal actions are needed to be revised to redraft the boundaries. In our observations, we understood that the demarcation process of the forest areas has been done without the participation of the farmers. Due to this process, some of the functioning tanks have been categorized under forest areas and sometimes some parts of the tanks have been demarcated as forest areas. This is one of the major issues of the Karuwalagaswewa hotspot area.

The study investigates the willingness of the farmers for several activities such as to find places for disposing the silted soil from rehabilitated tanks, resolve encroachment in drainage areas amicably among themselves, resolving encroachment in catchment areas amicably among themselves, adopt new water management practices which have been developed by farmers' organizations, adapt new water-saving technologies, practices, and crops, as mutually agreed and promoted by farmers' organizations, develop and implement a plan for farmer-managed tank/system maintenance in their cascades.

Community cooperation: The settlers of the cascades are disgusted by some of the government services provided for the agricultural sector. Especially, the farmers believe that some of the agricultural services like providing irrigation water, marketing, and tank renovation processes are politicized and biased. According to the data, it is quite evident that although some of the tanks have been renovated several times, some tanks have not been renovated at least once during the last 50 years. In these cascades, caste-based racism is very high. This conflict is hidden but comes out when sharing water, land, and renovating the tanks. The tanks which serve lower-caste communities have not been given priority. This should be a significant factor to be considered in the process of selecting the tanks for renovations. Anyway, many of the farmers are happy to support the cascade renovation process under the participatory approach.

Encroachment is very common in all the cascades in the hotspot area. The command areas of the cascades have been extended by $35-40 \%$ due to the encroachments. Some of the essential components of the tanks of the cascades have fully encroached and some of them have partially encroached. Most of the tanks in the hotspot area have no interceptors, silt traps, tree belts, and filters. Consequently, the cascade system is endangered and malfunctioned.

Average farm size of the command areas:

Figure 04 shows that the average farm sizes of the command areas are varied depending on the historical process of the land ownership, population growth, size of the tanks, and functional level of the tanks. For example, the average sizes of the farmlands of all the cascades are varying from 0.69 acres to 03 acres. There is a significant gap between the smallest and the largest. Consequently, the income gap of the farmers has also been widened. The Neliwewa cascade shows the biggest difference between the smallest (1.6 acres per family) and the largest ( 03 acres per family). These intra and inter inequalities of the land sizes have created income inequality along with a social exclusion among the families and the communities of the cascades. 
Figure 04: Inequality of land distribution among the cascades in Karuwalagaswewa DSD area

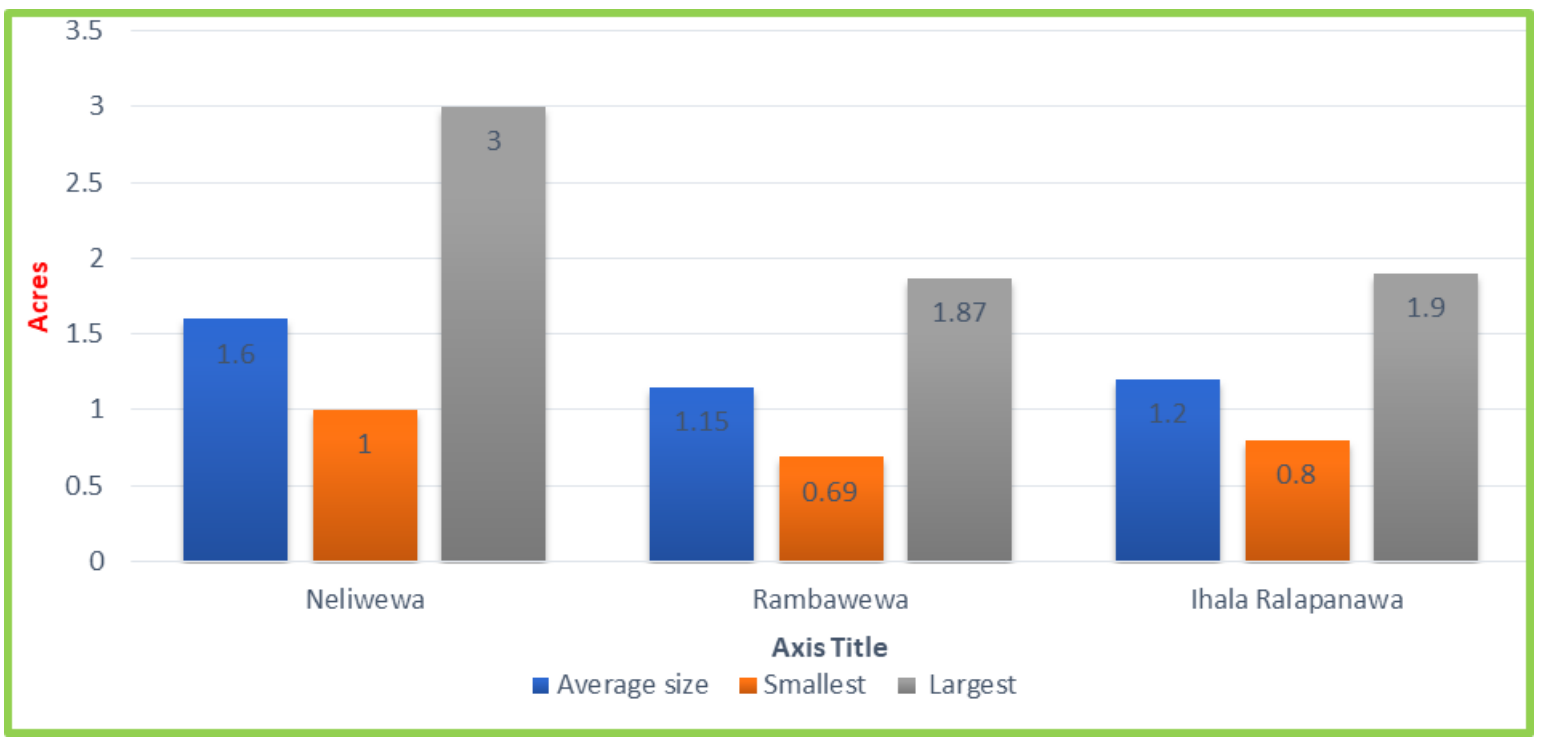

Source: PRA Results, 2020, Collected by the author

Crop varieties cultivate in the highlands: 04 percent of the farmers have been practicing organic agriculture with traditional crops. High-yielding varieties are grown in both the highlands and homesteads. Farmers are now being adopted to cultivate drought-resistant varieties under the guidance of agriculture officers as a new trend and it has to be improved and promoted at the same time. One of the major issues faced by the farmers is the lack of reliable sources of seeds in the open market system. Though 06 percent of the farmers produce seeds themselves in their farms for their needs, the main source of seeds is the private sector. According to our observations, the knowledge of the farmers on producing seeds should be enhanced. Seeding and planting mechanisms of the cascade areas of the Karuwalagaswewa hotspot area can be identified under 03 categories as transplantation (paddy, fruits, cashew, chili), broadcasting (paddy, green gram bean, sesame, black gram), and seeding (cereal \& legumes, luffa. okra, long bean).

Water Supply: The average number of hours of water flow required to irrigate one acre by crop and season in the normal rainfall years has been calculated. Paddy consumes more water than other crops that have been cultivated in the tank command areas such as groundnut, and watermelon and they are the best drought-resistant crops as they consume a very low amount of water compared to paddy. According to the data in figure 05, paddy is the highest water-consumed crop and watermelon is the lowest.

\section{Figure 05: Average number of water supply hours by crops and seasons}

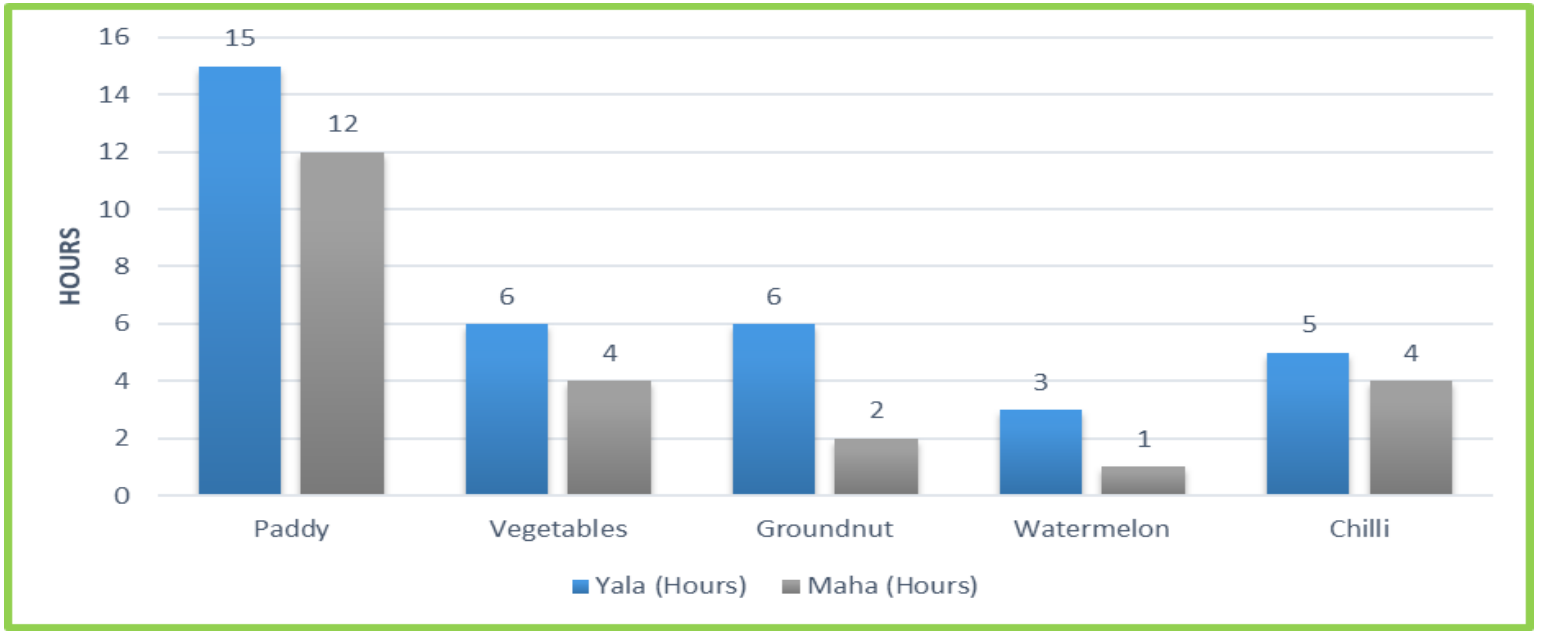

Source: PRA results, 2019/2020

Labor Use: Paddy, maize, watermelon are the most laborintensive crops and they require more hours for protecting the crops from wild animals. It seemed to be that some of the farmers have given up crop cultivation because of these wild animal invasions. According to our field experiences, we were able to understand that a particular set of farmers cultivate all the command areas in one season and hand over these lands to another set in the upcoming season as a strategy to reduce the labor hours. The slow population growth and the high rate of out-migration have been identified as the major hurdles for supplying the laborers. As a result, intensive subsistent agriculture has rapidly been mechanized. Cereals and legumes require more attention and labor in the Maha season than in the Yala season. Chili is the most laborintensive crop of the hotspot area and it takes 720 labor hours per acre (see fig. 06). 
Figure 06: Labor use per acre by Crop and Season in Karauwalagaswewa hotspot area

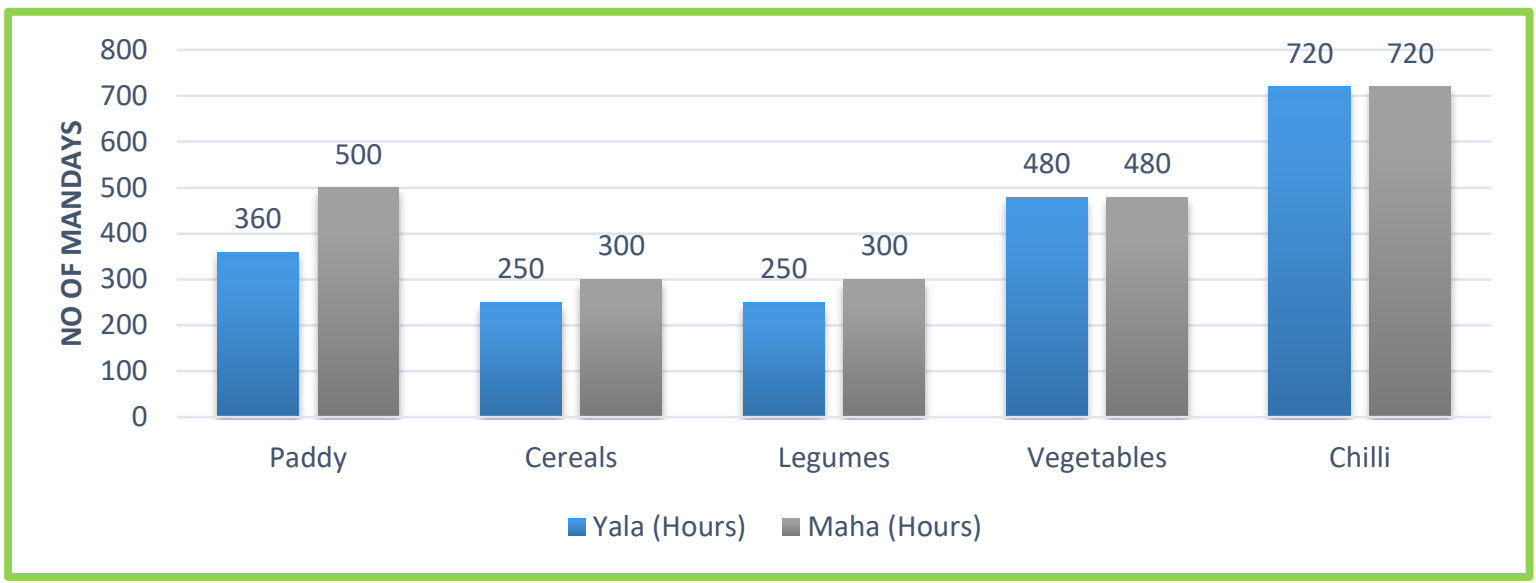

Source: PRA results, 2020, collected by the author

Fertilizer, pesticide, and weedicide usage: Chemical fertilizer usage by season is equal for all crops. Urea is the most common fertilizer for all crops. The data shows that all the seasonal crops are highly dependent on chemical fertilizer. 85 percent of farmers are addicted to using more agrochemicals for a better harvest. According to our observations, many of the farmers do not possess a scientific understanding of agrochemicals and agrochemical usages. This may ultimately cause CKD and different types of diseases among the farmers and consumers of these productions.

Cultivation costs and income of major crops: The study reveals the cost of farm machinery per acre by crops and season in the hotspot area. The data proves that water pumping is the costliest usage due to lack of irrigation water in both the seasons for highland and homesteads while all the other costs remain normal compared to the other areas of the district. According to the data, water pumping is necessary to make the cultivation successful in both seasons due to the lack of irrigation water supply. Four-wheeled and twowheeled tractors are mainly used for field preparation. The combined harvesters are much popular for paddy harvesting and seeding the maize in the hotspot area. Average cultivation costs of paddy, chili, watermelon, and groundnut per acre are 41, 000 LKR, 70,000 LKR, 86,000 LKR, 30, 000 LKR respectively. Although watermelon is the costliest crop in the DSD according to the data, it is the most profitable crop. According to the data, cashew is the most profitable perennial crop in the homestead and highland and watermelon is the most profitable crop in highland cultivation. All the farmer products except for paddy, have been produced for the market to gain profits. There is a trend to cultivate cashew and watermelon as they can be grown in both seasons (see Table 03)

Table 03: The average income from acre by crop and season

\begin{tabular}{|c|c|c|c|}
\hline Crops & Cultivation area & Yala (Rs) & Maha (Rs) \\
\hline Paddy & Command area & $1,21,000.00$ & $77,000.00$ \\
\hline Coconut & Highland, and homestead & $1,80,000.00$ & $90,000.00$ \\
\hline Groundnut & Highland & $1,60,000.00$ & $1,44,000.00$ \\
\hline Maize & $\begin{array}{l}\text { Command area, and high- } \\
\text { land }\end{array}$ & $1,50,000.00$ & $2,40,000.00$ \\
\hline Sesame & $\begin{array}{l}\text { Command area, and high- } \\
\text { land }\end{array}$ & $80,000.00$ & 00 \\
\hline Millet & $\begin{array}{l}\text { Command area, and high- } \\
\text { land }\end{array}$ & $1,20,000.00$ & 00 \\
\hline $\begin{array}{l}\text { Legumes (Green gram, } \\
\text { Cowpea, Black gram) }\end{array}$ & $\begin{array}{l}\text { Command area, and high- } \\
\text { land }\end{array}$ & $62,500.00$ & 00 \\
\hline Chili & $\begin{array}{l}\text { Command area, Highland, } \\
\text { and homestead }\end{array}$ & $800,000.00$ & $2,400,000.00$ \\
\hline Watermelon & Highland & $2,25,000.00$ & $900,000,00$ \\
\hline Cashew & Highland, and homestead & \multicolumn{2}{|c|}{$400,000.00$ (Perennial crop, harvest in Yala season) } \\
\hline Brinjal & Highland, and homestead & $3,60,000.00$ & $900,000.00$ \\
\hline Long bean & Highland, and homestead & $2,80,000.00$ & $800,000.00$ \\
\hline
\end{tabular}

Source: PRA results, 2019/2020, collected by the author

Climate-Smart Practices and Technologies: Status and Scope: The available farm practices for climate-smart agriculture of the cascades in the Karuwalagaswewa hotspot area have been concluded under the following 11 subheadings.

- Use of on-farm soil conservation practices
- Use of cultivation methods

- The extent of scope for crop diversification towards high-value crops

- The extent of scope for organic fertilizer by crop and seasons 
- The extent of scope for perennial crops, esp. in highland, tank bund, and other common areas of the cascade

- Extent or scope for horticultural crops both in tank command and homestead areas

- The extent of scope for mid-season, off-season cultivation

- The extent of scope for organic farming especially in Yala Season and also in homestead areas of the cascades

- The extent of scope for compost preparation with livestock manure, crop residues, and biomass, etc.

- Scope for promoting greenhouse farming with highvalue crops

- Scope for promoting community farming in common lands through producer groups

There are 03 major soil conservation practices in the hotspot area as mulching, land-leveling, and bunding. Mulching is a popular and traditional practice in chili, seasonal fruits, and vegetable cultivations. Land-levelling is practiced in paddy, maize cereal, legumes, fruits and vegetables, and watermelon cultivation while bundling is carried out in paddy, cereal, legumes, fruits, and vegetable cultivation.

Though they use these traditional practices, they do not have a common practice to protect the soil layer because of several reasons. Tanks are located in a terraced pattern based on the shape and the slope of the cascade system and due to that water flows from one tank to the other. Meanwhile, tree belts and the filters of the tanks have been encroached on by the farmers. Subsequently, during the land preparation periods for the paddy cultivation, the mud water with eroded debris directly flows to the next tank. As a result, all the tanks of the cascades in this hotspot area are full of silt. The second reason is Chena cultivation. Chena farmers do not practice any of these soil conservation methods and it directly has caused soil erosion. On the other hand, the Kayan tanks which have especially been designed for reducing soil erosion have been converted to Sorrow wewa to supply water for the command areas.
Cultivation Methods: In our field observations, we identified that the farmers do not possess a sound scientific knowledge of these conservation practices. It is essential to conduct awareness programs followed by the introduction of the appropriate conservation methods for the hotspot area and in the meanwhile, re-establishment of tree belts and filters is also very important. Three major cropping systems have been identified as inter-cropping, multiple cropping, and multi-storied cropping in the hotspot area. Banana under coconut, banana, and ginger under coconut, pineapple under coconut, aloe vera, and ginger under the banana, pepper under coconut, pomegranate with soursop, ginger, turmeric, and vegetable like capsicum under betel leaf have been identified as the combinations which come under inter-cropping. Coconut with orange, coconut with cashew, coconut with ginger, coconut with pineapple fall under intercropping method, and Multi-cropping method has been applied for coconut with pineapple, aloe vera, coconut with pomegranate, pineapple, orange, lemon and banana, cashew with green gram, cowpea. Vegetable, betel leaf with ginger and turmeric, mixed crops have been cultivated under the multi-cropping method. Generally, the raw method can be seen in coconut, mango, cashew, groundnut, maize, and legume cultivations. According to our field observations, we identified that the traditional and informal cultivation methods have been updated and upgraded in the hotspot area.

Scope for Crop diversification towards High-value Crops: Depending on the traditional practices and the current commercial marketing context under the open economy, there are some possibilities for crop extensions. Table 04 shows the possible crops and acres in the cascades of the Karuwalagaswewa hotspot area in the Puttalam District. Aloe vera, turmeric, and cashew are the most profitable and suitable commercial crops trending in the area because of the higher demand from private companies and their subsidies to promote the crop. The second and third possible scope for crop diversification is ginger and turmeric. All these figures clearly show that the farmers' attitudes have been changing from traditional crops to commercial crops on behalf of the profits.

Table 04: Scope for crop diversification in Karuwalagaswewa hotspot area

\begin{tabular}{llr}
\hline Crop & Scope & Acers for crop diversification \\
& Yes/No & 119 \\
Aloe-Vera & Yes & 146 \\
Ginger & Yes & 219 \\
Turmeric & Yes & 25 \\
Dragon Fruit & Yes & 175 \\
Cashew & Yes & 01 \\
Katuwelbatu & Yes & 22 \\
Tobacco & Yes & 22 \\
\hline
\end{tabular}

Source: PRA Results, 2019/2020, collected by the author

\section{Organic agriculture}

The survey points out that paddy is the most suitable crop for organic agriculture. Even though, the farmers are hoping to use organic fertilizer for paddy cultivation they point out that it reduces production. Perennial fruits like guava, pomegranate, mango, banana, coconut have been selected for organic cultivation as they rarely use chemical fertilizer for these crops. On the other hand, the farmers are trying to reduce chemical fertilizer and other agrochemicals because of the risk of kidney disease. Anyway, supplementary scientific knowledge is required to promote that.
The extent and scope for perennial crops in highland, tank bund, and other common areas of the cascades have been recognized by the PRA. Coconut is the only crop that can be cultivated in all three areas of the cascades and the cultivation can be extended up to 335 acres. Cashew is one of the commercial crops in the area. As a drought-resistant crop, there is a high scope to extend it in common and highland areas of the DSD. Teak is a good alternative for afforestation in the highland areas (See table 05). 
Table 05: The extent and scope for perennial crops

\begin{tabular}{llr}
\hline Crop & Places & Acers \\
\hline Coconut & Common & 125 \\
& Highland & 120 \\
& Homestead & 90 \\
\hline Cashew & Common & 15 \\
& Highland & 60 \\
\hline Teak & Highland & 4 \\
\hline
\end{tabular}

Source: PRA results, 2019/2020, collected by the author

\section{Horticulture}

There are positive responses among the young farmers for horticulture, but they need to have training. One of the averages and common trends in traditional agriculture is the lack of youth participation. Farmers generally think that the uneducated or lower educated people should work on farms. The young generation wants to change that mindset. Using this kind of technology, the youth will engage in agriculture again. There is a satisfactory scope for the cultivation of lime, fruits, and vegetables (see table 06).

Table 06: Extent and scope for horticultural crops both in tank command and homestead areas

\begin{tabular}{llr}
\hline Crop & Places & Acres \\
Vegetables & Homestead/Command area & 17.5 \\
Banana & Homestead & 16 \\
Aloe-Vera & Homestead & 09 \\
Orange & Homestead & 12 \\
Mango & Homestead & 35 \\
Fruits & Homestead & 17 \\
Lemon & Homestead & 18.5
\end{tabular}

Source: PRA results, 2019/2020, collected by the author

Table 07: The extent and scope for organic farming by season and in homestead areas

\begin{tabular}{llr}
\hline Crop & Season & Acers \\
\hline Vegetable & Both & 43.25 \\
& Yala & 21 \\
& Maha & 30 \\
\hline Chili & Both & 01 \\
\hline Watermelon & Both & 03 \\
& Yala & 05 \\
\hline Ginger & Both & 04 \\
Aloe-Vera & Both & 04 \\
Groundnut & Maha & 15 \\
Sunflower & Yala & 50 \\
\hline
\end{tabular}

Source: PRA results, 2019/2020, collected by the author

Extents for organic farming: As explained earlier, the farmers have no strong idea to cultivate crops in the highlands under organic methods. Anyhow, they are happy to experiment with organic farming in their homestead at a very low scale. Vegetables, perennial fruits, and paddy in the Yala season are the crops that are possible to be cultivated under organic farming methods. Table 08 shows that the vegetable is the most common crop cultivate under the organic farming method and 43.25 acres are cultivated in both seasons. In Yala season, 50 acres of sunflower and 40 acres of paddy are cultivated as organic farming in the hotspot area (see tables $07 \& 08$ for more detail).

Table 08: the scope and extents for organic farming in the hotspot area.

\begin{tabular}{llr}
\hline Crop & Season & Acers \\
\hline Vegetable & Both & 43.25 \\
& Yala & 21 \\
& Maha & 30 \\
\hline Chili & Both & 01 \\
\hline Watermelon & Both & 03 \\
& Yala & 05 \\
\hline Ginger & Both & 04 \\
\hline Aloe-Vera & Both & 04 \\
\hline Groundnut & Maha & 15 \\
\hline Sunflower & Yala & 50 \\
\hline Paddy & Yala & 40 \\
\hline
\end{tabular}

Source: PRA results, 2019/2020, collected by the author

Compost production: Currently, though there is no proper

to produce their agricultural products using compost withcompost production process, farmers are very much happy out using agrochemicals due to kidney disease. Farmers 
need both attitudinal and technological transformation with practical activities. There is a reliable possibility to produce compost using livestock manure, crop residues, and biomass of $20,000,30,000$, and $25,000 \mathrm{~kg}$ in a year respectively. The current annual compost production of the hotspot area is $1000 \mathrm{~kg}$.

Scope for Promoting CSA Practices: There is a significant possibility to promote greenhouse farming in the hotspot area. There are some trained youth farmers in the village. Young educated farmers are happy to apply new knowledge and technology to change traditional farming in the villages. The young farmers expect to reduce pest attacks and to cul- tivate organic high marketable crops using greenhouse technology. They would like to start on a small scale during the training period and then expand. Some of the landless farmers are happy to engage in community farming in common lands as they don't have adequate lands in the cascade to engage in cultivation. On the other hand, the farmers who have small lands are willing to engage in community farming because of higher bargaining power and strengthening of the farmer organizations. There is a satisfactory possibility to introduce different crops which can resist droughts and withstand salinity. Paddy, vegetables, cereal (cowpea, sesame, groundnut), chili, fruits, sunflower, and tobacco are the crops that are possible to be cultivated in the hotspot area (see table 09).

Table 09: Scope for introducing and expanding the salinity, and drought-resistant crop varieties by season

\begin{tabular}{llr}
\hline Crop & Season & Acers \\
\hline Paddy & Both & 178 \\
\cline { 2 - 3 } & Yala & 269 \\
\hline Aloe Vera & Both & 25 \\
\hline Vegetables & Both & 15 \\
\hline Cereal (cowpea, sesame, groundnut) & Both & 56 \\
\hline Chili & Yala & 40 \\
\hline Fruits & Both & 14 \\
\hline Sunflower & Both & 20 \\
\hline Tobacco & Both & 10 \\
\hline
\end{tabular}

Source: PRA Results, 2020, collected by the author

More than 95\% of farmers' burning issue is the lack of water for agriculture. Though they have surplus rain in the Maha season, they have no fully functional cascade system to store the surplus rainwater received during the rainy season. Due to these failures, they suffer both droughts in the dry period and floods in the rainy season. The farmers are coping with the situation in different traditional ways. Therefore, it is very important to promote water-saving technologies to the Karuwalagaswewa hotspot area. Table 10 concludes the farmers' perspectives in relevance to the water-saving technologies. The use of lift irrigation is the most popular water-saving technology in the hotspot and 321 acres are cultivated during the Yala season under this method. Watermelon is one of the crops that has been identified as a drought-resistant crop and it is cultivated 86 acres in Yala season.

Table 10: Scope and extents for promoting water-saving technologies

\begin{tabular}{llr}
\hline Crop & Season & Acers \\
\hline Paddy & Both & 178 \\
\cline { 2 - 3 } & Yala & 269 \\
\hline Aloe Vera & Both & 25 \\
\hline Vegetables & Both & 15 \\
\hline Cereal (cowpea, sesame, groundnut) & Both & 56 \\
\hline Chili & Yala & 40 \\
\hline Fruits & Both & 14 \\
\hline Sunflower & Both & 20 \\
\hline Tobacco & Both & 10 \\
\hline
\end{tabular}

Source: PRA Results, 2019/2020, collected by the author

Methods of marketing in the Hotspot area: The methods of marketing in the hotspot area are illustrated in this section. It shows the different strategies that have been practicing in the area. According to field observations, all these marketing methods are not sustainable because of market unpredictability. Due to these reasons, a considerable amount of harvest has to be dumped as waste. Some of the farmers have been practicing forward sales agreements with different private sector companies only for paddy. Previously, they had some agreements but all those have collapsed by now due to lower production, drought, decisions of the companies, and farmers' attitudes.

Generally, there are no proper marketing strategies except for traditional marketing in the cascades but some of the farmers practice forward sales agreements at a very private level in the area. Sometimes ago, they had forward sales agreements with some supermarket chains but it has collapsed by now. Therefore, they need new marketing strategies. In the cascade, one of the major problems is the availability of storage facilities because there is a high risk to lose the harvest due to elephant attacks and other wild animals like rats. Therefore, they request proper storage facilities and also price fluctuations. Unfair practices of the traders, lack of regulations to control such malpractices have taken place due to lack of storage facilities in season, and the offseason. Lack of transport facilities in and around the cascade due to unavailability of market roads or unsuitability of their conditions is another common problem faced by the farmers in the hotspot area. Issues regarding the processing of agricultural products have not been reported mainly due to the non-involvement of the farmers in the processing activities except for rice milling in the hotspot area. 
At present infrastructural facilities for joint marketing, processing, and proper common storage are not available in the hotspot area. On the other hand, there are no proper producer groups that are formed in the region but there is a high possibility to form producer groups. Farmers indicated that such facilities are important to obtain a high level of income from farming. According to the PRA results, the markets for paddy and cashew have to be developed. The cashew and dragon fruit farmers are looking for market facilities to maximize profits and value-added practices.

Demand for Storage Facilities by Crop: According to the PRA results, there is no type of marketing strategies that have been practiced in the area. At the same time, none of the farmers adopt processing and post-harvesting technologies. Farmers have only limited storage capacities (maximum 20\% of the production per season) in their residential areas. Everybody wants almost all the types of technologies to be adopted to obtain a high-income level by producing quality products for the market. However, experts' ideas and suggestions must be considered in selecting interventions to be implemented by the project.

A similar situation can be seen in other crop sub-sectors namely OFCs, vegetables, and fruits. At the same time, farmers indicate that the same type of interventions must be implemented to enhance their bargaining power to get a higher price for other agricultural products. Farmers demand storage facilities for paddy, maize, and groundnut. There is a high amount of cow milk production in the villages and the milk farmers sell the total amount of milk to the outside collectors. Consequently, thousands of liters of milk are wasted due to the absence of these outside collectors. Depending on this reason, they expect common storage facilities for milk. The needs and demands of the farmers for processing options have been recognized by the PRA team. A large number of animal husbandry farms are located in the Puttalam district and residues of crops like Maize can be used to feed the animals.

PRA has recognized joint marketing activities especially from the producer groups and change farm organizations to firm or producer organizations to sustainably face the market requirements. As explained earlier in this report, these smallholders produce small-scale production and if they practice joint productions, they will be able to supply it for the medium-scale markets. In the survey, the tanks in all the cascades have been categorized into 03 as Forest, Olagam, and Purana tanks. The majority of the tanks in the division have come under the Purana wewa and this is $88.7 \%$. There is only one Olagam wewa and 09 Forest tanks in the 03 cascades. Though these are the forest tanks, they are encroached and used for agriculture in different ways except for 02 abandoned tanks.

The condition of the tank bed is a major issue that always communities have highlighted during all the discussions. Therefore, this directly impacts the water capacity of the tanks. Under the PRA investigations, the main status of the tanks' beds is categorized into 05 groups. There are only 02 tanks that are in good condition, and 52 tanks must be designed to make sure that there is a sustainable water supply from the tanks. However, there are 04 tanks to remove vegetation in the tank beds.

The existing condition of the sluice gates of the tanks is divided into 05 categories. Consequently, 05 sluices gates are in good condition while 45 have to be renovated. The farmers have proposed to relocate the 01 sluice gate and 16 gates will be newly fixed. According to our observations, it is essential to conduct an engineering survey before the renovation. There are no sluice gates in some forest tanks because they are still working as forest tanks.

Famers verified that there are 10 spills in good condition and 31 spills are needed to be renovated. One of the spills have to be relocated and 13 spills needed to be newly established after technical investigations in the 03 cascades. The existing state of the catchment is evaluated under the 08 criteria. Accordingly, it was found that the catchments of most of the tanks are not in a good condition and only 21 tanks are in a good condition while 02 are in a critically depraved condition. There are 14 thanks to soil erosion and 18 consists of vegetative growth and 10 have encroached.

The existing situation of the feeder canal systems is not at a satisfactory level and only 17 out of 220 channel systems are in a good condition. 06 feeder canals have encroached and 06 are under obstructing water inflow. Vegetation has grown in 15 feeder canals and 03 canals consist of salinity while 13 are having soil erosion. There are no canals in the 03 tanks and another 04 are under the water logging settings.

There is only one embankment which is in a good condition and all the other 61 embankments are needed to be renovated. The situation of the tank bunds is directly obstructing the water storage of the tanks. According to the PRA records, the majority of the tanks overflow annually.

Command area; status and issues of the tanks and the anicuts: Status and issues of the command areas of the tanks and anicuts are concluded in this section. There are two major issues about these cascades. Some of the tanks are fully functioning and the command land area of these tanks is greater than the designed capacity of the tanks due to forest land encroachments. On the other hand, in the command areas of the malfunctioning tanks at least the designed capacity of the tanks cannot be cultivated due to inadequacy of water. The major reason for these issues is the individual rehabilitation of the tanks. These issues can be mitigated by rehabilitating the overall cascade as a system. The total designed capacity of the tanks in the 03 cascades of the hotspot area is 1496.6 acres. However, the tanks in the area come under the minor irrigation category because of the small size of the command areas. Consequently, the actual area of cultivating command area is about 1,511.5 acres because of the encroachments.

According to the contemporary situation, 84 canals are available in the cascades in 11 command areas without proper distribution. 47 canal systems have been constructed by using soil and others have been constructed using soil and cement. The current condition of the canals has been assessed under 10 criteria. Accordingly, 08 canals are under seepage and 35 canals are partially damaged. There is no encroachment and 04 of the canals consist of silt, 07 are in critical condition and 06 canals are inefficient. As per the data, only 10 canals are functioning smoothly, and all the other canals need to have different types of renovations for them to function smoothly.

The land slope of the cascades is grouped into 03 categories. Accordingly, there are 04 command areas located on the high slope category and 45 on low-level areas. Another 12 command areas are located on a very low slope and they are waterlogged. The land in the area is slightly high in salinity and 480 acres of the land area is affected by salinity. During the Yala season, paddy cultivation is limited due to a lack of water. Therefore, crop cultivation is limited to 650 acres. As per the information, the new extent of paddy cultivating 
lands after system rehabilitation will be increased by 1,111.5 acres in Yala and Maha seasons.

Irrigation Management status and issues of the tanks and the anicuts: As per the collected data 47, 554 farmers depend on getting irrigation water for the Yala season while 1078 families are obtaining water facilities in the Maha season for Paddy and other crop cultivations. There is unsatisfactory participation of farmers to maintain the farmer organizations. The farmers of 28 tanks have actively contributed to sustaining their organizations. The majority of farmers in 31 tanks have not satisfactorily been contributed to strengthening their farmer organizations due to many reasons.

Most of the farmers' organizations are quite organized and the farmers who cultivate under 57 tanks have funds in bank accounts while farmers in 02 tanks have no such accounts in the banks.

Farmers from 19 tanks have pointed out that there is no effect of water allocation for the Yala season in the evaluation process of water allocation rules of the Yala season. However, farmers of 40 tanks have mentioned that the water distribution system is effective. There are water-sharing conflicts among the farmers in 20 tanks while farmers from 39 tanks have reported that there are no water-sharing conflicts. Most of the tanks have a systematic control of irrigation water supply for the command areas. The water inspector (locally called Jalapalaka) carries out the main role of managing the water distribution as assigned by the farmer organizations. 47 tanks have this type of management system for water distribution while 12 tanks in cascades still do possess such a systematic process.

\section{CONCLUSION}

Currently, though the farmers have some traditional CSA practices, the modern CSA practices are not in action in the Karuwalagaswewa DSD in Puttlam district. Hence, to implement such activities it is needed to change the existing agricultural practices. In this regard, it needs a proper mobilization process and a solid technical assistant from the experienced officers to promote CSA practices. The second priority in the three-cascade training on CSA technologies and practices is to design and implement capacity building program followed by proper training.

As per the findings, training and awareness programs on CSA technologies and practices are needed. Accordingly, it is recommended to design and implement a capacity-building program for the farmers with suitable training and assessment. There is a large potential to introduce such practices. Also, there are some aquatic plants available in the tanks which can be utilized to produce compost and it will help to secure the tanks' beds as well.

The paddy fields in the Karuwalagaswewa area are smaller and they can be used to practice and introduce the interpreted pest management systems and other collective CSA practices. The knowledge of post-harvesting management is very low in the two ACSs and such practices can be introduced in these areas to enhance the income of local communities. The seed and plant material supply are not enough to stand in all the DSDs. Therefore, it is needed to systematize the supply change of seed and other inputs for sustainable outcomes from farming.

Home gardening is another potential area that can enhance the income and agricultural products of the area. Women are actively engaging in home gardening-related activities. This can be improved as an alternative income generation option and it will also increase the food security of the DSD. This can be introduced to all the cascades and the model projects will be the best community mobilization tool in this regard.

As per the findings of the PRA consultation, there is a larger potential to introduce a water management system on CSA practices. This can be considered as one of the priority actions in CSA. The soil conservation practices in almost all the cascades are unsatisfactory and the substitute answer can be found by promoting home gardening in homesteads and highlands.

There are more than $90 \%$ farmers in the 03 cascades of the Karuwalagaswewa division having more than an acre highland. Therefore, there will be a vast potential to introduce perennial, annual, and seasonal crops for highlands to enhance their annual income. However, most of the farmers who cultivate in such lands do not have legal documents to endorse their ownership. Karuwalagaswewa is highly vulnerable to wild animal threats and it has to be considered when selecting the crops for CSA practices. It will be best to consider introducing wild animal-resistant crops under the CSA program.

It was found that during the PRA consultation hiring machinery reserves is a difficult task for them due to lack of enough machinery. Then they have prioritized the lack of equipment as a major problem. Also, there were deficits in types of equipment, different prices, and conditions, etc. Accordingly, there is a big demand for such services and it is needed to be addressed by the project appropriately through the government system, private, public partnership, or farmer cooperatives.

The trust of crop insurance in the cascade is dissatisfactory as well as most of the frames are not much aware of the benefits of having insurance. The government has compulsorily registered the farmers for crop insurance because without having crop insurance, the farmers are ineligible for fertilizer subsidy. Accordingly, it will be a good option to introduce such a system. The major problem of the current insurance scheme is that it doesn't cover the crop damages from wild elephants, monkeys, wild boars, giant squirrels, etc. Also, there is no proper coordination and communication between the officers who are attending and facilitating the services to the community.

\section{REFERENCES}

Department of Census and Statistics (2019). Agriculture Household Survey, http://www.statistics.gov.lk/Agriculture/Staticallnformation/new/AHS2016-17Report.

Department of Meteorology (2020). Retrieved from; https://meteo.gov.lk/index.php?option=com_content\&view=article\&id=94\&ltemid=310\&lang=en on February 7, 2021.

Resource Profile (2019), Divisional Secretariate Karuwalagaswewa, Puttalam District

Dharmasena, P.B. (2015). Essential Components of Traditional Village Tank Systems. In: Proceedings of the National Conference on Cascade Irrigation Systems for Rural Sustainability. Central Environmental Authority, Colombo.

Emerton, L. (2005). Values and Rewards: Counting and Capturing Ecosystem Water Services for Sustainable Development. IUCN. p. 93.

Puttalam District Statistical Handbook (2019), District secretariate, Puttalam

Madduma Bandara, C.M., (1985), Catchment Ecosystems and Village Tank Cascades in the Dry Zone of Sri Lanka, in "The Geo-Journal", Reidel publishing company, Dortrecht.

Maria S. R. (2007). "Analytical Framework with Empirical Results from the Kala Oya Basin, Sri Lanka". Researchgate.net. p. 8. Retrieved Feb- 
ruary 7, 2021. https://www.researchgate.net/publication/288858185_Evaluating_Institutional-Impact_Interactions_in_the_Context_of_MDGs_Analytical_Framework_with_Empirical_Results_from_the_Kala_Oya_Basin_Sri_Lanka

Mendis, G. C. (1952). Ceylon under the British. Asian Educational Services, New Delhi

Ministry of Irrigation and Water Resources Management (2015). Reservoirs of Sri Lanka, Retrieved from; https://www.irrigation.gov.lk/index.php?option=com_gmapfp\&view=gmapfp\&layout=article\&Itemid=221 on February 8, 2021.

Panabokke CR (2009). Small village tank systems of Sri Lanka: their evolution, setting, distribution, and essential functions, Hector Kobbekaduwa Agrarian Research and Training Institute, Colombo

Panabokke, C. R. (2002). Small tanks in Sri Lanka: evolution, present status, and issues. IWMI.

Panabokke, C.R., (1999), The Small Tank Cascade Systems of the Rajarata: their Setting, Distribution Pattern and Hydrology. Mahaweli Authority of Sri Lanka - International Irrigation Management Institute, Colombo.

Report of the Land Commission of Sri Lanka (1990), retrieved from; https://www.historyofceylontea.com/ceylon-publications/otherpublications/1987-report-of-the-land-commission-P026/quickview/index.php, on November 30, 2020.

Sakalasooriya, N. (2021). Sustainability of the Minor Irrigation Systems of the Cascades in Dry Zone of Sri Lanka: Challenges and Potentials; $A$ Cultural Ecological Analysis, in International Journal of Science, Arts, and Commerce (IJSAC), ISSN: 0249-5368, Vol.6 No. 02, February 2021 International Research and Knowledge Publications (IRKP), Dhaka, Bangladesh PP 70-93.

Sakalasooriya, N. (2020), Samaja Sameeksha-05, in Vitharana, L.D.S. (ed.) (In Sinhala), "Ellanga Hewath Helmalu Wew Pokuru" Samaja Parisarika Paddhathiyak Lesa, (Cascade or Terraced Tanks Clusters as a Social-Ecological System, Department of Sociology, University of Kelaniya

Sakalasooriya, N. (2019). Significance of Forest Tanks (Kuluwew) Renovations in the Cascade Tank Systems (Ellanga) in Dry Climatic Zone of Sri Lanka: The Cases from the Cascades in Puttlam District, International Postgraduate Research Conference 2019, Faculty of Graduate Studies, University of Kelaniya, Sri Lanka. P. 180

Tennakoon, M.U.A., (2005), Ellangawa (in Sinhala). Godage and Sons, Colombo

Tennakoon, M.U.A., (2012), Tank Terminology, South Asia Partnership. Sri Lanka, https://www.sapsri.lk/tank-terminology/ retrieved at 5.45 January 23, 2021

Tennakoon, M.U.A., (2015), Tank Terminology, South Asia Partnership. Sri Lanka, https://www.sapsri.lk/tank-terminology/ retrieved at 5.45 January 23, 2021

The World Bank, 2020, https://www.worldbank.org/en/topic/climatesmart-agriculture

Sri Lanka: Rivers (2019). FAO http://www.fao.org/3/T0028E/T0028E02.htm retrieved on February 19,2021 